\title{
A TALE OF TWO COURTS: THE 'CREATION' OF A JURISDICTION?
}

\author{
Elizabeth Chadwick *
}

I asked at The Hague, and again at Paris, whether it was really necessary that a terrible war should take place before a criminal Court could be constituted, or that some crime which shocked the civilised world should be committed, before such a Court can be set up.

H.E. Megalos Caloyanni ${ }^{I}$

\begin{abstract}
Two projects to create the international criminal courts were devised during the 20th century. On 1 July 2002, the Rome Statute of the Intemational Criminal Court entered into force. On 16 November 1937, the Convention for the Creation of an International Criminal Court was opened for signature at Geneva. The latter never entered into force, an event made contingent on the coming into force of its companion Convention for the Prevention and Punishment of Terrorism, which also never occurred. The use to be made of law in each court forms the core of this discussion: the Rome Statute Court will rely on both vertical and horizontal approaches to the exercise of jurisdiction, and will utilise a harmonised approach to substantive criminal law; the 1937 court would have utilised domestic criminal law, in that the intent behind the 1937 convention was to make available an alternate forum, should the need arise. It is argued in particular that a horizontal approach to international criminal law may hold more seeds of future discord than a vertical approach, as harmonised law-making and enforcement lack a muchneeded critical foundation. Crucially, the new International Criminal Court could greatly disturb the existing distribution of power and authority originally designed into the United Nations Charter, and effect a major shift in power politics, thus upsenting the balance between the principle of non-interference in state domestic affairs and the maintenance of international peace.
\end{abstract}

\section{INTRODUCTION}

On 1 July 2002, the Rome Statute of the International Criminal Court (ICC) entered into force. ${ }^{2}$ Adopted, and opened for signature in Rome on 17 July 1998,

* Senior Lecturer, Nottingham Trent University, Nottingham, UK.

1 H.E.M. Caloyanni, 'The Proposals of M. Laval to the League of Nations for the Establishment of an International Permanent Tribunal in Criminal Matters: Lecture to the Grotius Society, 4 July 1935' (1935) 21 Grotius Transactions 77, 86.

2 UN doc. A/CONF. $183 / 9$ (17 July 1998), reprinted (1998) 37 ILM 1002. Sixty ratifications were needed for the ICC to come into force. ICC, article 126. As of 5 September 2003, 91 states had ratified. The ICC is not an organ of the United Nations, although the two organizations will have formal relations. ICC, article 2. 
this was a historic event for many reasons. ${ }^{3}$ The jurisdiction of the ICC is to extend, as stated in article 5, to 'the most serious crimes of concern to the international community as a whole': crimes against humanity, and of genocide, war, and aggression. ${ }^{4}$ The ICC is the culmination of a project commenced soon after the Second World War, ${ }^{5}$ and hopes for its future success and ultimate effectiveness run high.

Nonetheless, concrete efforts to achieve consensus with regard to an international criminal court did not begin so recently. A much earlier attempt at consensus was the opening for signature and ratification in 1937 of the Convention for the Creation of an International Criminal Court (ICC 37). ${ }^{6}$ The subject matter jurisdiction of the ICC 37 was limited to 'terrorism', in the wide sense of 'making progress in the struggle against offences of an international character, ${ }^{7}$ and the 'repression of conspiracies or crimes committed with a political or terrorist purpose'. ${ }^{8}$ Unfortunately, the ICC 37 never entered into force, ${ }^{9}$ an event made contingent on the coming into force of its companion Convention for the Prevention and Punishment of Terrorism (Terrorism Convention) which also never occurred.10 Had these instruments done so, however, a new international jurisdiction would effectively have been created.

Today's ICC also entails what could be viewed as a new jurisdiction, one resting on a body of international criminal law which has only recently been acknowledged

3 See, e.g., M.-C. Roberge, 'The New International Criminal Court: A Preliminary Assessment' (December 1998) 325 IRRC 671; 1. Tallgren, 'Completing the "Intemational Criminal Order"' (1998) 67 Nordic JIL 107; P. Sob, 'The Dynamics of International Criminal Tribunals', ibid., 139; 'Colloquium' (1998) 3 Journal of Armed Conflict Law.

4 Regarding the crime of aggression, see below notes 45 , and 159-160, and accompanying text.

5 The United Nations General Assembly asked the International Law Commission to study the possibility of establishing an international tribunal, through which jurisdiction over certain convention crimes, such as genocide, could be exercised. See UNGA Resolution 260(III)B, UN doc. A/760 (1948), reprinted (1949) UNYB 959, 960; P. Bouzat, 'Introduction', in M.C. Bassiouni, A Drafi International Criminal Code and Draft Statute for an Intermational Criminal Tribunal (1987) xiii.

6 League of Nations Document, C.547(I).M.384(I).1937.V., reprinted 7 Hudson, International Legislation, No. 500, 878; opened for signature 16 November 1937 . See, e.g., Editorial Comment, Hudson, 'The Proposed International Criminal Court' (1938) 32 AJIL 549; Notes, Starke, 'The Convention for the Creation of an Intemational Criminal Court' (1938) 19 BYIL 216; A. Sottile, 'Le Terrorisme Intemational' (1938) 65 Recueil des Cours 91, 139-178; United Nations Secretary-General, 'Historical Survey of the Question of International Criminal Jurisdiction', UN doc. A/CN.4/7/Rev. 1 (1949) at 16-18 (Historical Survey).

7 Preamble to the ICC 37.

8 Resolution IV of the League of Nations Council, quoted in Caloyanni, loc. cit., 80-81; Sottile, loc. cit., 143.

9 As of 1 January 1941, no state had ratified the ICC 37.

10 League of Nations Document, C.546(I).M.383(1).1937.V., reprinted 7 Hudson, International Legislation. No. 499, 863; opened for signature 16 November 1937. The Terrorism Convention was to come into force ninety days after the deposit of three ratifications or accessions. Article 26(1)(2). Only those states which ratified or acceded to the Terrorism Convention could ratify or accede to the ICC 37. As of 1 January 1941, India alone had ratified the Terrorism Convention. Editor's Notes, 7 Hudson, International Legislation, ibid., 862, 878 . 
to exist. ${ }^{11}$ As such, the new court is reliant on the somewhat contentious notion that an international legal community, one imbued with a degree of autonomous sovereign force, exists. This, in turn, implies that an aggregation of individual state wills is capable of co-ordinated action. Somewhat more contentiously, the ICC is to apply a harmonised law to criminal acts. Heretofore, acts deemed 'criminal', if prohibited at all, have been so under disparate national laws, ${ }^{12}$ even though a strong bias towards Western ideals is indeed increasingly apparent within the many socialstructural frameworks of domestic criminal law. While a barmonised approach to criminal law has led to some apprebension that, in time, a majority of states could validly and authoritatively bind the minority,$^{13}$ the growing importance of measures such as procedural fairness, equal protection norms, and rights of defence, ${ }^{14}$ do in fact imply a certain consensus may be emerging.

In contrast, domestic criminal law would have been applied by the ICC 37 . The intent behind the convention was to make available an alternate forum, should the need arise. The associated 1937 Terrorism Convention was merely a treaty to conform the prohibition of political terrorism. In turn, the vertical approach to jurisdiction adopted in the ICC 37 was reflective of the long-standing tradition of prosecuting crime in cases where there exists a sovereign or territorial link, the breaking of which by an enforcing state in order to reach international criminals can be a valuable tool of international justice. 15 Thus, even though the socialstructural origins, and consequences, of criminal law often differ on a state-by-state basis, ${ }^{16}$ a consistency in substantive principle would have been possible in each case,

11 See, e.g., C.J.M. Safferling, Towards an Intemational Criminal Procedure (2001) 35-44, who characterises intemational criminal law as 'human rights-centric'. See also ICC, article $21(3)$.

12 The definition of genocide, ICC, article 6, was taken from the 1948 Genocide Convention, which contemplated both international criminality and an international court in which to try the offence. No nexus to an armed conflict is required for crimes against humanity. ICC, article 7. Contrast practice in this regard under the Nuremberg Charter, see note 66 below, article $6(\mathrm{c})$, and Indictment Count 4. Jurisdiction over serious war crimes, 1CC, article 8 , is largely based on relevant provisions of the four Geneva Conventions of 1949, and two Protocols of 1977.

13 Of interest see C. Douzinas, 'Postmodern Just Wars: Kosovo, Afghanistan and the New World Order', working paper in possession of the author.

14 A. Woodiwiss, Making Human Rights Work Globally (2003) 15.

is For example, a theory of universal jurisdiction may be applied, via national criminal jurisdiction, for war crimes or piracy, because of general enforcement obligations. M.C. Bassiouni, 'Universal Jurisdiction for International Crimes: Historical Perspectives and Contemporary Practice' (2001) 42 Virg. JIL 81, 101 n.70, 118. Contrast G. Tremlett, 'Spanish PM refuses torture extradition', The Saturday Guardian, 30 August 2003, 18 (judicial request to extradite 40 Argentinian torturers to Spain prevented by the government).

16 See, e.g., H. Kelsen, The Communist Theory of Law $(1976,1955) 102 ;$ C. Silverman, 'An Appeal to the U.N.: Terrorism Must Come Within the Jurisdiction of an International Criminal Court' (1997) at <gopher//gopher.igc.apc.org/00/orgs/iccingodocs/terrorism_ silverman.txt> (a comparison of US, Iranian, and Cuban criminal justice systems in relation to air piracy and hijacking). But see A. Stille, 'Historians Trace an Unholy Alliance: Religion and Nationalism', NYTimes.com, 31 May 2003. 
rising from within the organic base ${ }^{17}$ of each signatory state's particular political philosophy. ${ }^{18}$

Accordingly, it is a matter of concern that the ICC will rely on both vertical and horizontal approaches to the exercise of jurisdiction, ${ }^{19}$ as the construction of a harmonised law with which to prosecute the nominated crimes may mask what is in effect a political and philosophical 'hijacking' of international crime control by special interests. ${ }^{20}$ The inherent instability of interaction between the political aspects of state sovereignty and a notional international legal community also raises a danger that an 'autonomous' body of international criminal law will result in inconsistency. ${ }^{21}$ While the ICCs of 1937 and 1998 thus constitute very different approaches to an age-old problem, namely the difficulty of making 'criminal' some uses of force in international life, it is the purpose of this discussion to explore briefly the use of law made through each court initiative. This is done in order to introduce the theme that a borizontal approach to the enforcement of international law may hold more seeds of future discord than a vertical approach which relies on individual state respect for treaty obligations.

The structure of this discussion is as follows. First, the structure of the ICC 37 is outlined, after which the provisions highlighted are contrasted with the relevant provisions of the present ICC. The origins and purpose of each court project are then outlined in order to locate within the prevailing legal and political environment the respective merits of a vertical versus a borizontal approach to international criminal jurisdiction.

\section{A COMPARISON: THE INTERNATIONAL CRIMINAL COURTS OF 1937 AND 1998}

The ICCs of 1937 and 1998 are obviously different, if only in regards to their respective lengths. The ICC 37, as a tribunal dependent on the coming into force of the Terrorism Convention, extends to a mere 56 articles. ${ }^{22}$ The present ICC, a much more ambitious project in terms both of jurisdiction, procedure and detail, extends

17 By which is meant the foundation to natural, systematic growth rather than mere historical development. See L. Oppenheim, The League of Nations and Its Problems (1919) 5, 10-14.

18 But see S. Sedley, 'No More Victors Justice?', London Review of Books, 2 January $2003,14$.

19 ICC, article 13. See notes 46-51 and 68-70, below and accompanying text. See generally section 4 , below.

20 The Statute is a heavily compromised document. For example, the Vatican, Catholic and Islamic states exerted pressure to limit to heterosexuals the article 7 proscription of persecution on grounds of gender. Sedley, loc. cit., 16. See also Oppenheim, op. cit., 44, para. XII.

21 Which is a different issue to the sovereignty problem in relation to human rights, in that human rights limit the enforcement of human rights. Safferling, op. cit., 48.

22. The ICC 37, when combined with the Terrorism Convention on which it was dependent, extends to 85 articles. 
to 128 articles. Moreover, the two tribunals are strikingly different in terms of structure, scope of jurisdiction, and choice of law.

\subsection{Issues of Jurisdiction and Admissibility: The ICC of 1937}

Commentary in 1933 indicates that, as 'the rules of international law concerning the repression of terrorist activity are not at present sufficiently precise to guarantee efficiently international co-operation in the matter, ${ }^{23}$ primary attention should be focused on proscribing certain offences. ${ }^{24}$ A French initiative, the ICC 37 required states to retain control over terrorist prosecutions. Seizing the ICC 37 was merely an option: each High Contracting Party 'shall be entitled, instead of prosecuting before [its] own courts, to commit the accused for trial to the Court'.25 Thus, a referring High Contracting Party had to ratify both the Terrorism Convention and the ICC 37, have competence either to prosecute or extradite, ${ }^{26}$ and choose to delegate its competence to the ICC. ${ }^{27}$ In turn, the ICC 37 would sit 'only when it is seized of proceedings for an offence within its jurisdiction', ${ }^{28}$ It was to be a permanent body at The Hague, ${ }^{29}$ and was to establish its own regulations regarding practice and procedure. ${ }^{30}$

Article 1(2) of the Terrorism Convention defines 'acts of terrorism' as:

Criminal acts directed against a State and intended or calculated to create a state of terror in the minds of particular persons, or a group of persons or the general public.

Articles 2 and 3 provide for jurisdiction ratione materiae: an act of terrorism of an international character was committed on the territory of one High Contracting Party, and directed against another. Article 2 of the Terrorism Convention requires High Contracting Parties to make criminal the following acts:

Each of the High Contracting Parties shall, if this has not already been done, make the following acts committed on his own territory criminal offences if they are directed against another High Contracting Party and if they constitute acts of terrorism within the meaning of Article 1:

Resolution IV, quoted in Caloyanni, loc. cit.

Editorial Comment, Kuhn, 'International Co-operation in the Suppression of Crime' (1943) 28 AJIL 541, 543.

Article 2(1).

Terrorism Convention, article 5, states, subject to national law, that 'each High Contracting Party shall provide the same punishment for the acts set out in Articles 2 and $3, \ldots$.

Sottile, loc cit., 151.

ICC 37, article 3 . This would occur when a High Contracting Party committed an accused to the court for trial. Article 25(1).

Although it could meet elsewhere. ICC 37, article 4.

Article 15. 
(1) Any wilful act causing death or grievous bodily harm or loss of liberty to:

(a) Heads of States, persons exercising the prerogatives of the head of the State, their hereditary or designated successors;

(b) The wives or husbands of the above-mentioned persons;

(c) Persons charged with public functions or holding public positions when the act is directed against them in their public capacity.

(2) Wilful destruction of, or damage to, public property or property devoted to a public purpose belonging to or subject to the authority of another High Contracting Party.

(3) Any wilful act calculated to endanger the lives of members of the public.

(4) Any attempt to commit an offence falling within the foregoing provisions of the present article.

(5) The manufacture, obtaining, possession, or supplying of arms, ammunition, explosives or harmful substances with a view to the commission in any country whatsoever of an offence falling within the present article.

Article 3 prohibits conspiracy or incitement, as follows:

Each of the High Contracting Parties shall make the following acts criminal offences when they are committed on his own territory with a view to an act of terrorism falling within Article 2 and directed against another High Contracting Party, whatever the country in which the act of terrorism is to be carried out:

(1) Conspiracy to commit any such act;

(2) Any incitement to any such act, if successful;

(3) Direct public incitement to any act mentioned under heads (1), (2) or (3) of Article 2, whether the incitement be successful or not;

(4) Wilful participation in any such act;

(5) Assistance, knowingly given, towards the commission of any such act.

Jurisdiction based on territoriality, nationality, and universality governed the option to cede a case to the ICC. Specifically, territorial jurisdiction exists should the offence be committed on the territory of the referring High Contracting Party; grounds of nationality are contemplated should the perpetrator(s) of a terrorist offence abroad retum to national territory. Finally, universal jurisdiction, as when a proscribed offence is committed abroad by a non-national, is inherent in the 'internationalising' of the article 2 offences specified in the Terrorism Convention. ${ }^{31}$ reprinted (2001) 42 Virg. JIL at 157; Sedley, loc. cit., 16. 
The court was to be available to any state which preferred not to deal directly with what might be a matter of some delicacy, making the ICC 37 highly progressive. ${ }^{32}$ There was, however, no obligation on states to make use of the court, and no 'right' of an accused to be tried before it. As noted by Hudson, ${ }^{33}$

The striking innovation in this Convention lies in the co-operation provided for to relieve States of embarrassing burdens cast upon them more or less accidentally and at the same time to assure to other States due regard for their special interest in repressing terronist activities outside their own borders.

\section{2,2 Issues of Applicable Law: The ICC of 1937}

The ICC 37 carried no independent or superior function in terms of international law. The operation of the court was premised on the transposition of national criminal laws to the international plane, thus obviating any need to devise new law, as such. ${ }^{34}$ Article 19 provides, in pertinent part, as follows:

... [P]rovided the offender is not allowed to escape punishment owing to an omission in the criminal law, the characterisation of the various offences ...., the imposition of sentences, the methods of prosecution and trial, and the rules as to mitigating circumstances, pardon and amnesty are determined in each country by the provisions of domestic law. [Emphasis added.)

Article 21 of the ICC 37 governs the choice of law as follows:

(1) The substantive criminal law to be applied by the Court shall be that which is the least severe. In determining what that law is, the Court shall take into consideration the law of the territory on which the offence was committed and the law of the country which committed the accused to it for trial.

(2) Any dispute as to what substantive criminal law is applicable shall be decided by the Court. ${ }^{35}$

Notes, Starke, loc. cit.. 215. Articles 8,9, and 10, concern the duty to prosecute, or extradite an accused, for articles 2 and 3 offences. Articles 13 and 14 deal with municipal low measures as to passports, firearms, and explosives. Articles 15, 16, and 17 deal with interstate police co-operation, which, one commentator notes, was likely to be more effective in the prevention of terrorist outrages than strict municipal law reform. Provision for the resolution of inter-state disputes over jurisdiction and admissibility is made in ICC 37, articles 45 and 48 .

Editorial Comment, Hudson, op. cit., 553-554.

See, e.g., Notes, Starke, loc. cit., 217.

s. Article 22 provides that '[i]f the Court has to apply, in accordance with Article 21, the law of a state of which no sitting judge is a national, the Court may invite a jurist who is an acknowledged authority on such law to sit with it in a consultative capacity as a legal assessor'. 
Thus, although the national laws of signatory states would have been bounded by articles 2 and 3 of the Terrorism Convention, and the prosecution of terrorist offences no longer solely a matter of sovereign discretion, much scope for variation remained. The principle of punishment, alone, was emphasised. ${ }^{36}$ The continued application of domestic criminal laws and enforcement procedures was to provide the backbone of this limited exercise in international co-operation, thereby reflecting a more organic result in each case. Moreover, the use of domestic law before the court would have served to expose any gaps in a state's legal approach to terrorist offences of an international character.

Nonetheless, one commentator remarked in 1938 that the ICC 37 'is to be classified under the head of international criminal procedure', ${ }^{37}$ as post-referral procedures were specified in the convention. A case could be referred to the court only after the referring state had carried out its own investigations into the matter. ${ }^{38}$ Any state entitled to seize the court of a particular matter could inspect the file, and participate in the formal proceedings. Provision was also made for persons injured by an offence to constitute themselves as partie civiles before the court. ${ }^{39}$ Accused persons were to be legally represented, and informed of the case against them. ${ }^{40}$ Article 34 provides additional safeguards as follows:

No examination, no hearing of witnesses or experts and no confrontation may take place before the Court except in the presence of the counsel for the accused and of the representatives of the States which are taking part in the proceedings or after these representatives have been duly summoned. ${ }^{41}$

Witnesses could be summoned and heard. Proceedings were to be in public unless the court decided they should be held in camera. Deliberations were to be secret, but judgment pronounced publicly. ${ }^{42}$ Decisions were to be by majority, and the reasoning stated..$^{43} \mathrm{~A}$ judgement would have had international juridical effect between the High Contracting Parties. Sovereign states would thus have retained ultimate control over the suppression of politically-motivated terrorism having an international character, and the extent to which the court would be utilised. The ICC 37 provided an auxiliary forum in which to hear an already-prepared case, and perhaps more importantly, political distance from responsibility for the judgment.44

\footnotetext{
See section 3.3 note 126 below.

Notes, Starke, loc. cir., 217.

ICC 37, article 23.

Articles 26 and $39(2)$. In effect, this permitted representations as to danages.

Articles 29 and 30 .

This provision did not prevent conviction in absentia.

2 Article 35.

43 Article 38. No provision is made for a written judgment.

44 Sottile, loc. cit., 159.
} 


\subsection{Issues of Jurisdiction and Admissibility: the 'Rome' ICC}

Except for the crime of aggression, the crimes listed in ICC, article 5, were in large part established or given definition as international crimes during, or immediately after, the Nuremberg and Tokyo war crimes tribunals. For the ICC to have jurisciction over the crime of aggression, however, article 5 must be amended, as follows:

The Court shall exercise jurisdiction over the crime of aggression once a provision is adopted in accordance with articles 121 and 123 defining the crime and setting out the conditions under which the Court shall exercise jurisdiction with respect to this crime. Such a provision shall be consistent with the relevant provisions of the Charter of the United Nations. ${ }^{45}$

Moreover, article 124 permits a state party to declare it does not accept the court's jurisdiction over war crimes for a period of seven years after entry into force of the statute for that state. As a result, the exercise of jurisdiction as envisaged appears somewhat piecemeal, as two of the four crimes listed in ICC, article 5, are made deferrable in terms of jurisdictional competence.

Jurisdiction will also be differently privileged. ICC, Part 2, articles 5-21, cover jurisdiction, admissibility and applicable law. Article 13 provides as follows:

The Court may exercise its jurisdiction with respect to a crime referred to in Article 5 in accordance with the provisions of this Statute if:

(a) A situation in which one or more of such crimes appears to have been committed is referred to the Prosecutor by a State Party in accordance with Article 14;

(b) A situation in which one or more of such crimes appears to have been committed is referred to the Prosecutor by the Security Council acting under Chapter VII of the Charter of the United Nations; or

(c) The Prosecutor has initiated an investigation in respect of such a crime in accordance with Article 15.46

Bassiouni notes ${ }^{47}$ that the ICC does not establish universal jurisdiction in the context of state referrals under article 13(a), as the court is not intended to replace national jurisdiction over article 5 crimes. The present ICC is thus based on 'complementarity', similar to the ICC 37 ; it was early recognised that the project would

45 ICC, article 5(2). This means not before 2009.

46 See H. Smith, 'Athens Lawyers' Hague case names PM, Straw and Hoon', The Guardian, 29 July 2003, 11 (on 28 July 2003, the Athens Bar Association lodged a complaint with the Prosecutor alleging the perpetration of crimes against humanity and war crimes during the 2003 Iraq War).

47 Bassiouni, loc cit., 106. 
founder if this were not the case. ${ }^{48}$ What is created is a universal scope to the crimes within the jurisdiction of the ICC, leaving intact the verticality of state enforcement mechanisms.

However, referrals by the UN Security Council do constitute the exercise of universal jurisdiction, as they can transcend the territoriality of a state party-this is the borizontal aspect of the ICC's reach. ${ }^{49}$ There are no preconditions to the exercise of jurisdiction under article 13(b). The Security Council, acting by resolution adopted under chapter VII of the UN Charter, may also defer an investigation or prosecution for twelve months, renewable..$^{50}$ Of perhaps greatest contrast to the ICC 37, however, are the provisions made in articles 34 and 42 for the office of the prosecutor as an organ of the court, and the power in article 13(c) for independent prosecutorial initiative. Thus, should a state otherwise having jurisdiction be 'unwilling or unable genuinely to carry out the investigation or prosecution', article $13(\mathrm{c})$ may come into operation. ${ }^{\$ 1}$

\subsection{Issues of Applicable Law: The 'Rome' ICC}

The creation and/or progressive development of an ascertainable, substantive body of international criminal law is one purpose behind the ICC. The Rome Statute provides for the adoption of the elements ${ }^{52}$ of the article 5 crimes, and rules of procedure and evidence,,$^{53}$ by a two-thirds majority of the members of the Assembly of State Parties to the convention. Accordingly, the ICC was designed to promote a more 'unified' approach to the prosecution of article 5 crimes. Questions remain, however, as to whether the exposure of gaps in related domestic coverage will be rectified, as the system of 'complementarity' would seem to permit a degree of forum shopping.

As regards the prioritisation of legal source, article 21 provides that the court is, first, to apply 'this Statute, Elements of Crimes and its Rules of Procedure and

48 Preamble, and Article 1. See Current Developments (1996) 90 AJIL 496. Tallgren characterises 'complementatity' as 'sewing the Emperor's new clothes'. Tallgren, loc. cit., 119, and 'Epilogue', 135-137. Sedley, loc cit,, 16, terms it 'subsidiarity', as 'the ICC is there only to do jobs that states themselves will not or cannot do'. The primacy of a national judicial system over its own citizens may still be asserted when the Prosecutor begins to look into a situation. ICC, articles $18(2)$ and $19(2)$ (b). As for competing requests by the court or a state for transfer of a 'wanted person', see Articles 90 and 94.

49 Bassiouni, loc, cit., 106.

50 Article 16. The US, a non-ratifier, insisted deferral remain open to Prosecutorial review for six months. Article 18(3). See The Lawyers Committee for Human Rights, 'The International Criminal Court: The Case for U.S. Support', 8, at <gopher. igc.apc...ngodocs/us\&icc_Ichr.txt>.

51 See article 17. Article 18 governs preliminary rulings regarding admissibility, and article 19 governs challenges to either jurisdiction, or admissibility.

52 Article 9. 'Elements of crimes shall assist the Court in the interpretation and application of Articles 6, 7, and 8. Article 9(1).

53 ICC, article 51(1). The judges may remain flexible. Article 51(3). 
Evidence', after which, and where appropriate, it is to apply applicable treaties and 'the principles and rules of international law'. ${ }^{54}$ Any possible similarity with the ICC 37 in this regard must await reference to article $21(1)(\mathrm{c})$, which provides in pertinent part as follows:

Failing that, general principles of law derived by the Court from national laws of legal systems of the world including, as appropriate, the national laws of States that would normally exercise jurisdiction over the crime, ....

The trial is governed by ICC, part 6 . Article 63 mandates that the accused 'shall be present during the trial', unless his or her presence is disruptive, at which point the accused shall be permitted 'to observe the trial and instruct counsel from outside the courtroom'.55 Provisions governing procedural matters are extensive, and include choice of language(s) for use at trial, the attendance and testimony of witnesses (who are to receive protection), the production of documents and other evidence, the rights of the accused, the presumption of innocence, and the conditions under which an accused may plead guilty. ${ }^{56}$ Proceedings are to be in public. ${ }^{57}$ The judges must strive for unanimity, failing which a majority decision will be determinative. Deliberations are to be in secret, but decisions, or their summary, delivered in writing in open court. Should a majority decision occur, the judgment 'shall contain the views of the majority and the minority'. ${ }^{58}$ Sentences are to be 'pronounced in public and, wherever possible, in the presence of the accused" ${ }^{59}$

\section{WHY AN INTERNATIONAL CRIMINAL COURT?}

\subsection{General}

The issue of an international criminal court is completely separate to that of an international criminal jurisdiction. ${ }^{60}$ As for the latter, the UN Secretary-General submitted in 1949 a Memorandum to the General Assembly in which the question of international criminal jurisdiction is historically surveyed. It is noted that the best-known examples in customary international law of delicta juris gentium, or 'crimes against the law of nations', are piracy, and war crimes. ${ }^{61}$ The recognition of

\footnotetext{
Part 3, articles 22-33, list general principles of criminal law.

Thus, no allowance is made for conviction in absentia.

ICC, part 6, articles 62-76.

Article 67(1). Provision is made for hearings in camera. Article 68(2).

Article 74.

Article 76.

Historical Survey, loc. cit., 1.

61 Until the Nuremberg Trial, loc. cit, the word 'crime' in the expression 'war crimes' was not taken in its technical sense, i.e., the most serious on the scale of criminal offences, but rather in the general sense of the non-fulfilment of an obligation under domestic criminal law regardless of its seriousness. ILC Report, 1996, chp. II, Part II, Commentary on Article 20 (war crimes), paragraph 6, at <http://www.un.org/law/ilc/reports/1996/chap02. htm>.
} 
these crimes permitted departures from the normal principles of domestic criminal jurisdiction. Other offences, dealt with through treaty, included the slave trade, the traffic in narcotics, women and children, the dissemination of obscene publications, the counterfeiting of currency, and the injury of submarine cables.

As for the former issue - that of an international criminal court - important considerations underlying the respective purposes of the 1937 and 1998 court projects reffect their era. Nonetheless, the impetus behind the two court projects is curiously similar: the need to ensure the punishment of terrorist actors. The ICC 37 was designed to deal with terrorist offences of an international character, and resulted specifically from a spate of diplomatic assassinations and what might be termed ongoing 'anarchist' activity. ${ }^{62}$ The ICC project, although begun in the early days of the United Nations, largely stalled during the Cold War, and was renewed only after the collapse of communism in Eastern Europe to deal, in part, with the perpetrators of acts of international terrorism. ${ }^{63}$

In view of the sixty-odd years that separate them, a primary issue in the comparison of the two courts must be that of the law to be applied. The use of domestic law by the ICC 37 , as a forum by default, would have reflected the basic premise that, in relation to crime, there was no international law. ${ }^{64}$ As states were viewed as the exclusive subjects of international rights and duties at that stage of international development, it no doubt was only possible to heighten the ceiling, if not raise the roof, of domestic state jurisdiction, through the creation of an 'international' criminal court which could afford a default forum. Moreover, the main emphasis was placed on the punishment of the perpetrators of certain offences, rather than on substantive or procedural uniformity.

It should also be remembered that the assertion of universal jurisdiction remains a separate issue to universal condemnation. ${ }^{65}$ Since the Nuremberg and Tokyo Military Tribunals, ${ }^{66}$ universality has been provided by treaty concerning

62 See Keesings Archives, 1393-1395. Prior attempts to repress political crime include a protocol providing measures against an anarchist movement, signed by nine states at St. Petersburg, 1-14 March 1904, and an administrative convention to exchange information about individuals dangerous to society, signed at Buenos Aires, 20 October 1935. Several bipartite agreements related to the suppression of terrorism, and many extradition treaties contained clauses exempting attempts against Heads of State from the list of political offences, for example, article 3(e) of an Extradition Convention signed at Montevide0, 26 December 1933. Editor's Notes, 7 Hudson, International Legislation, 878. And, drug-trafficking. See ILC Report, 1990, chp. II, paragraphs 20-158; (1990) 2(2) YBILC. See, e.g., Sedley, loc. cit., 16; D.J. Harris, 'Progress and Problems in Establishing an Intemational Criminal Court' (1998) 3 Joumal of Amed Conflict Law 1, 3. As such, it was long felt that the establishment of an international criminal court would be 'premature'. Historical Survey, loc. cit., 12.

65 For a discussion on this point, see Bassiouni, loc. cit., 89.

66 The Nuremberg Charter was annexed to the London Agreement of 8 August 1945, 5 UNTS 251, reprinted (Supp. 1945) 39 ANIL 257. The 'I.M.T. (Nuremberg) Judgement and Sentences, 1 October 1946', is reprinted (1947) 41 AIIL 172. The I.M.T. (Far East), convened in Tokyo on 3 May 1946 on similar grounds, rendered judgment on 4-12 November 1948. 
matters of general international concern, such as genocide. ${ }^{67}$ The present ICC represents a logical consequence of this trend, and further embodies a growing theme of the 20th century: as a minimum, individuals should enjoy the benefits, and accept the duties, of customary international law. This premise, in turn, flows from the doctrine 'that generally recognised rules of the law of nations form part of the law of the land'. ${ }^{68}$ There is thus, arguably, a continuing obligation on states to transform or transpose into their domestic spheres at least those rules of international law which are for the direct or indirect benefit of individuals, as well as to act in conformity with, in particular, customary international law, and any treaties to which they have assented.

Nevertheless, the relative value of a vertical approach to enforcement, in terms of a prescriptive capability employed against international crime, quickly becomes apparent; heretofore in international life, 'the criminal jurisdiction exercised by a state within its territory [has been] the product of a long development whereby the state has gained sovereignty within that territory. ${ }^{69}$ A vertical approach exposes gaps in the observance of the rights and duties imposed by international law, thereby, inter alia, encouraging the operation of the prosecute or extradite formula, mutual assistance in criminal matters, and general rules of interstate comity. The extra-territorial reach of national legislation may, in any event, overlap or coalesce with the enforcement of universal legislation to reach international crimes. ${ }^{70}$

In contrast, a horizontally-harmonised approach to the definition of crime, to prosecution and procedure, and to sentencing, may conceal levels of dissonance over the particulars, such as those of interpretation. In other words, as the assignment of a legal qualification to an act merely denotes the fact that subsequent assessments of responsibility and liability can be made, 'paper law', alone, is not enough. There is thus a real risk not only that the jurisdiction of the new court will be exercised erratically, but further, that what judgments it does produce could appear highly political, if not politicised. In any event, the ICC has an extremely limited jurisdiction, and would thus represent a cautious exercise in harmonised law-making. Further, its competence should normally be restricted to the ratifying parties.

However, to the extent that a horizontal approach to the exercise of jurisdiction over particular international crimes of violence represents something of an unknown in international life, it is of interest that a non-ratifying US remains

Article 6 of the 1948 Convention on the Prevention and Punishment of the Crime of Genocide, 78 UNTS 277, reprinted (Supp. 1951) 45 AJIL 6. The convention received unanimous approval in UNGA Resolution 260(III) of 9 December 1948.

68 D.J. Harris, Cases and Materials on International Law (3'd edn., 1983), 122, excerpting H. Lauterpacht, U.N. Memorandum (1949) (citation omitted). But see the ICC. Preamble: 'Recalling that it is the duty of every State to exercise its criminal jurisdiction over those responsible for international crimes'.

69 'Question of International Criminal Jurisdiction', ILC doc. AVCN.4/20 (1950), reprinted (1950) 2 YBILC 20 (UN doc. A/CN.4/SER.A/1950/Add. 1, 6 June 1957) 20, para. 15. See also Oppenheim, op. cit, 9-10, para.V, 13-16, paras VIII and IX. 
strongly opposed to its operation, primarily on the basis that the court's competence may not prove to be so limited in relation to the citizens of non-ratifying states. More concretely, the US continues to show itself ready and willing to bribe member states to derogate from their treaty obligations in relation to US citizens and interests, which places the very rationale of the ICC somewhat in doubt. ${ }^{71}$ The origin of each court project is now reviewed in order to orient, later in this discussion, the structure of each within its political environment.

\subsection{The ICC of 1937}

The notion of an international criminal court or tribunal, for the prosecution of acts deemed by the world community to be international crimes, began to receive serious academic study during the 19 th century. ${ }^{72}$ By 1919 , public support rallied behind the victorious Allied powers to prosecute violations of the laws of war and humanity perpetrated largely by Germany during the First World War ${ }^{73} \mathrm{~A}$ Commission on the Responsibility of the Authors of the War and on the Enforcement of Penalties suggested to the Paris Peace Conference ${ }^{74}$ that an ad hoc international tribunal, for the trial of certain 'acts which brought about the war and ... particularly the violation of the neutrality of Belgium and Luxembourg' should be convened..$^{75}$ The Committee, in synopsis, concluded that

[E]very belligerent had by international law the power and authority to try individuals for war crimes but that an international tribunal was essential for

$\eta$ As of 7 August 2003, the US had negotiated 'Impunity Agreements' (or 'Article 98 agreements') with 53 states. For several, there was the immediate restoration of US aid. See E. Becker, 'U.S. Suspends Aid to 35 Countries Over New International Court', and 'U.S. Presses for Total Exemption from War Crimes Court', NYTimes.com, 2 July 2003, and 9 October 2002, respectively. But see 'Falun Gong sues under Belgium law', The Guardian, 21 August 2003, 16 (after protest by the US, Belgium's new genocide law was confined by sovereignty, territoriality, and immunity rules).

72 Sottile, loc. cit., 139; Caloyanni, loc. cit., 78; Bassiouni, op. cit., XI, 1-2.

73 Caloyanni, loc. cit., 78; Editorial Comment, Hudson, loc. cit., 549-550. Sottile, loc. cit., 139-140, refers also to the Treaty of Sèvres (not ratified) in which Turkish criminal responsibility was envisaged. The Sultan's government instead conducted two prosecutions for the 'genocidal' massacre of Armenians, the criminality of which was however never established. T. Taylor, The Anatomy of the Nuremberg Trials (1993), 18.

74 'Commission Report Presented to the Preliminary Peace Conference, 28 March 1919' reprinted (1920) 14 AJIL 95, 117-118, 121-124, and 'Annex II., U.S. Memorandum of Reservations', 127-151 ('[t]o the unprecedented proposal of creating an international criminal tribunal and to the doctrine of negative criminality the American members refused to give their assent', ibid, 129). For a comparative view in this latter regard, see J.W. Gamer, 'Punishment of Offenders Against the Laws and Customs of War', ibid., at 70, 90-94. See also Historical Survey, loc. cit., 7, and 8.

75 Editorial Comment, Hudson, loc. cit, 549 ; Historical Survey, loc. cit., 7 . The US reacted with doubt regarding "the uncertainty of liability for violation of the "laws of humanity" and the extension of its jurisdiction to charges against Heads of States'. Ibid., 8, and Appendix 2. 
the trial of certain charges. These were charges of crimes against persons of varying nationalities, e.g., atrocities in prison camps containing prisoners of war of more than one nationality, charges against persons of authority whose orders affected more than one nationality or operations against the armies of more than one of the Allies, and charges against the major enemy authorities and against any other persons whom it might not be desirable to try in any national court. ${ }^{76}$

Nothing came of this, but provision is made in article 227 of the Treaty of Versailles ${ }^{77}$ to try the former German Emperor, Kaiser Wilhelm, for 'a supreme offence against international morality and the sanctity of treaties'. An Allied extradition request to the Netherlands, where he had fled, was refused on the grounds that the offence charged against him was unknown to Dutch law, was not mentioned in any treaties to which the Netherlands was a party, and appeared political. ${ }^{78}$

Articles 228-230 of the Versailles Treaty provide for the prosecution of war criminals in Allied tribunals, ${ }^{79}$ and the Allies presented a 'wanted' list of 854 individuals on 3 February 1920 . What trials took place, before the Supreme Court in Leipzig, proved unsatisfactory, ${ }^{80}$ yet the effort to prosecute German war crimes reinforced interest in an international criminal jurisdiction, and a centralised tribunal. $^{81}$ A request by the Commission of Jurists to the League of Nations Assembly that same year, for a separate 'High Court of International Justice', was, however, not well received, largely because it included the question of state culpability. 82

In 1926, the International Law Association approved a draft 'Statute of the Court', action favoured by the International Association of Penal Law which adopted a resolution in support of an international criminal jurisdiction. ${ }^{83}$ The use of the Permanent Court of International Justice ${ }^{84}$ for this purpose posed a further

76 Synopsised in Historical Survey, loc. cit., 7.

77 Signed 28 June 1919, (1919) 225 CTS 189.

78 Taylor notes that the Allied camp was divided on the wisdom of the project, and the Dutch received hints that the demand was pro forma and there would be no coercion'. Taylor, op. cit., 16.

79 Identical provisions are contained in the peace treaty with Austria (articles 173-5), but not with Bulgaria. Garner, loc. cit., 70 n. 1.

80 In 1922, the Allies declared in a note to Germany that the Leipzig Court decisions would not be recognised as valid, and reserved all rights under articles 228-230 of the Versailles Treaty. Taylor, op. cit., 18; Tallgren, loc. cit., 113-114.

81 See, e.g., Editorial Comment, Hudson, loc. cit., 551 n. 11; the bibliographies in Sottile, loc. cit., 178-181.

82 Caloyanni, loc cit., 78; Editorial Comment, Hudson, loc. cit., 550; Sottile, loc. cit., 140; Historical Survey, loc. cit., 8-12.

83 Editorial Comment, Hudson, op. cit, 550-551; Sottile, loc. cit, 141; Caloyanni, loc. cit., 78.

84 Created under article 14 of the League of Nations Covenant, the jurisdiction of the PCIJ was limited to civil matters. 
option. ${ }^{85}$ Then, the third political assassination of $1934,{ }^{86}$ that of King Alexander I of Yugoslavia, occurred in Marseilles, on 9 October, during a state visit. The French Minister for Foreign Affairs, M. Louis Barthou, was also killed, and approximately 45 persons injured in the incident. The perpetrators belonged to an Croatian 'Oustachi' organization, the ultimate aim of which was to sever Croatia from Yugoslavia, and unite it in a new Austro-Hungarian-Croatian state. ${ }^{87}$

The extradition of persons accused of the Marseilles murders ${ }^{88}$ was refused by Italy on the ground that the crime was political; the accused were convicted 'par contumace', or in absentia, in France. ${ }^{89}$ On 10 December 1934, the French Minister of Foreign Affairs, M. Laval, presented a draft proposal to the Council of the League of Nations in which he urged the adoption of 'international measures' to separate and suppress terrorist crimes committed for political purposes, and a criminal court in which to try the perpetrators. ${ }^{90}$ Thus, the creation of an international criminal court specifically for the suppression of 'terror' crimes marked a new direction within a more general context of international co-operation to suppress and prosecute 'crimes' of international concern.

The League Council formed a Committee of Experts, with delegates from Belgium, Chile, the UK, France, Hungary, Italy, Poland, Rumania, the USSR, Spain, and Switzerland, to prepare two draft conventions. ${ }^{91}$ The first draft texts were completed in April 1935.92 The final texts, negotiated 1-16 November 1937, were opened for signature at Geneva, on 16 November 1937. Both conventions had a status independent of the PCIJ and the League, ${ }^{93}$ despite being League initiatives, as the League was already in difficulty. ${ }^{94}$ Twenty-four

There was also involvement by the International Law Association, the InterParliamentary Union, and the International Congress of Penal Law. The 1928 draft statute of the latter was revised in 1946. Historical Survey, loc. cit. 12-15.

86 The Austrian Chancellor was shot in Vienna, on $25 \mathrm{July,} \mathrm{as} \mathrm{was} \mathrm{the} \mathrm{Polish} \mathrm{Minister} \mathrm{of} \mathrm{the}$ Interior, in Warsaw, on 15 June. Keesings Archives, 1394, notes that 'during the past 80 years more than 100 Monarchs, Presidents, and heads of govemments have been assassinated'.

87 Keesings Archives, 1393-1395, 1405.

88 The secret headquarters of whom was in Budapest. Keesings Archives, p. 1405.

89 Editorial Comment, Hudson, loc. cit., $551 \mathrm{n}$. 20, citing Hudson, Cases on International Law ( $2^{\text {pd }}$ ed., 1936), $946 \mathrm{n}$. See also Gamer, loc. cit., 81-82.

90 LNOJ, 1934, 1731, 1839, cited in 7 Hudson, International Legislation, Loc cit, 862, 878. See also Editorial Comment, Kuhn, loc. cit.

91 LNOJ, 1934, 1759-1760, cited in 7 Hudson, International Legistation, loc. cit., 862; Editorial Comment, Hudson, loc. cit., 551 n.14.

92 See Sottile, loc. cit., 142-143; Caloyanni, loc. cit., 81-82.

93 The P.C.I.J. was however to select the ICC 37 judges. ICC 37, Article 7(2).

94 See Sottile, loc. cit, 161, 167. On 17 March 1933, Japan gave notice of withdrawal from the League, followed by Germany (21 October), Paraguay (23 February 1934), Guatemala (26 May 1936), Nicaragua (27 June 1936), Honduras (10 July 1936), Salvador (26 July 1937), and Italy (11 December 1937). The League of Nations 1920-1946: Organisation and Accomplishments (United Nations Library, 1996), 174-175. The outbreak of the Spanish Civil War, on 17 July 1936, showed the League polarised politically. See E. Chadwick, 'Back to the Future: Three Civil Wars and the Law of Neutrality', in E. Chadwick Traditional Neutrality Revisited: Law, Theory and Case Studies (2002), 177, 194-197. 
govemments signed the Terrorism Convention, ${ }^{95}$ and thirteen governments, the ICC 37.96

It was hoped that additional competencies could in time be added. ${ }^{97}$ As one commentator remarked in 1935, '[i]t seems extraordinary that inasmuch as a crime is a crime in a country, yet when it comes on to the international plane it should remain unpunished' ${ }^{98}$ The comment illustrates well the tradition of linking sovereign and territorial interests to the suppression and punishment of crime which would hold for much of the 20th century. Therefore, what was instead sought was a formal treaty basis to the 'universalised' exercise of jurisdiction over terrorist crimes of an international character, such as would result in punishment for the perpetrators, much in the same manner as the jurisdiction exercised to punish acts of piracy on the high seas, or the belligerent suppression of war crimes.

Approximately one year after the two terrorism projects came to fruition, the Second World War erupted. The decreasing restraint in the means and methods utilised to achieve victory effectively transformed what had been viewed as a positive international legal order of war law into a 'trial by arms', or 'just war'. To the extent that natural law concepts implying enduring ethical values superior to individual state interests came into play the Second World War could be characterised 'morally' ${ }^{99}$ In turn, a natural law philosophy in the sense of such a 'higher law' was inserted into the charters for the Nuremberg and Tokyo Military Tribunals, providing some evidence of 'the existence, side by side with positive law, of a natural law which was binding on all States irrespective of their will ${ }^{100}$ - in this case,

95 Albania, Argentina, Belgium, Bulgaria, Czechoslovakia, Cuba, Dominican Republic, Egypt, Ecuador, Estonia, France, Greece, Haiti, India, Monaco, Norway, the Netherlands, Peru, Rumania, Spain, Turkey, the USSR, Venezuela, and Yugoslavia, 'the signatures for Albania, Belgium, and Norway being ad referendum'. 7 Hudson, International Legislation, op. cit., $877-878$; Sottile, loc. cit, 120 . It is believed to be the first multilateral convention ever signed by India. No other member of the British Commonwealth was a signatory. Notes, Starke, loc. cit., 214-215.

* Belgium, Bulgaria, Czechoslovakia, Cuba, France, Greece, Monaco, the Netherlands, Rumania, Spain, Turkey, the USSR, and Yugoslavia 7 Hudson, International Legislation, op. cit., 893; Sottile, loc. cit., 120.

97 Sottile, loc. cü., 143:

La Cour pénale internationale a été créée, aux termes du Préambule, en vue de réaliser un progrès dans la lutte contre les infractions présentant un caractère intemational, et non pas contre les seules infractions terroristes a caractère international. Ceci montre que l'intention de la Conférence a été d'instituer une Cour, ayant pour le moment à s'occuper d'infractions terroristes internationales, mais pouvant acquérir plus tard d'autres compétences. (Emphasis in the original)

98 Caloyanni, loc. cit, 78.

99 Taylor notes that when, on 7 October 1942, President Roosevelt and the British Lord Chancellor (Sir John Simon) separately proposed the establishment of a UN Commission for the Investigation of War Crimes, President Roosevelt referred to 'atrocities which have violated every tenet of the Christian faith'. Taylor, op. cit., 226.

100 G.J.H, van Hoof, Rethinking the Sources of Intermational Law (1983) 106. 
the prohibition of certain crimes of violence in international life. ${ }^{101}$ This facilitated not only a finding of individual criminal responsibility, but further, of punishment premised on specific formulations of the notionally pre-existing international 'crimes' of aggression, of war, and against bumanity.102

Allegations of ex post facto law continued however to dog the Nuremberg and Tokyo trials in relation to the prosecution, by the 'victor' states, of those defeated for crimes against the peace, war crimes, the demise of the defence of superior orders, and crimes against humanity. ${ }^{103}$ The unconditional surrender, the Allied occupation, and the assumption of supreme authority over the German state by the four Occupying Powers permitted them to govern Germany, albeit in the name of the UN, in which, it was hoped, ultimate responsibility would inhere. Under these circumstances in particular, there could be no other courts in Germany than the investigatory and prosecutorial organs of the four powers. ${ }^{104}$ Nonetheless, jurisdiction was defended by the Nuremberg Court, in pertinent part, as follows:

The making of the Charter was the exercise of the sovereign legislative power by the countries to which the German Reich unconditionally surrendered .... The Charter is not an arbitrary exercise of power on the part of the victorious nations, $\ldots$ it is the expression of international law existing at the time of its creation.... The Signatory Powers created the Tribunal, defined the law it was to administer, and made regulations for the proper conduct of the Trial. In doing so, they have done together what any one of them might have done singly.... 105

The foundation for the assertion that any of the Signatory Powers alone might have tried the defendants pursuant to prevailing laws and procedures is located in the Preamble to the Nuremberg Charter, which declares that the Allies were acting in the interests of all the United Nations', that the Indictment expresses the common position of the four Powers, and that the charter was intended as a precedent for future use. An interface with reality is attempted by the equation between such laws and procedures, and the 'interests of all the United Nations' as determined by the US, the USSR, the UK, and France. ${ }^{106}$ As noted by van Hoof, the acceptance of

101 See note 66. On 11 December 1946, the GA unanimously adopted Resolution 95(1), affirming the principles of international law recognised in the Nuremberg Judgment. The International Law Commission declined to express any appreciation of these [Nuremberg] principles as principles of international law .... Harris, op. cit., 560.

102 See Historical Survey, loc. cit., 18-24.

103 Crimes against the peace were completely new. War crimes had not previously been prosecuted in an international forum, and 'superior orders' had previously constituted a defence. Crimes against humanity were limited by the court to events occurring after 1 September 1939, as the French in particular felt the charge had no foundation in international law. See Taylor, op. cit, 21-42.

104 See E. Chadwick, Self-Determination, Terrorism and the International Humanitarian Law of Armed Conflict (1996) 183-190.

105 'Judgement and Sentences', cited note 66, above, 216.

106 See E. Chadwick, 'To the Victors the (Legal) Spoils?', in Traditional Neutrality Revisited, loc. cit., at 129. 
some superior authority in international law, such that the majority of states may bind the minority, is premised on a natural, rather than a positive, law philosophy. ${ }^{107}$ The extraordinary conflagration of the Second World War, the unconditional surrender of Germany and Japan, and their territorial military occupations certainly facilitated such a unified stance.

\subsection{The 'Rome' ICC}

As previously remarked in relation to both ICCs, there is a common thread: terrorism. In turn, acts which are, or can be, termed 'terrorist' occur alongside new theories of warfare and military necessity, and new developments in weaponry. ${ }^{108}$ An agreed definition of terrorism for purposes of universal jurisdiction is thus as problematic as the prohibition of developments in new war technologies and statesponsored terror-methods. ${ }^{109} \mathrm{~A}$ recognition of this point early in the renewed postCold War negotiations thus resulted in a different approach taken to international crime in order to construct an international criminal forum, and a harmonised law. 110

Much earlier, however, and pursuant to UN General Assembly Resolution 175(II), the UN Secretary-General was instructed to begin 'the necessary preparatory work for the beginning of the activity of the International Law Commission'.111 Specifically, and pursuant to General Assembly Resolution 260(III)B of 1948, the ILC was requested to:

[S]tudy the desirability and possibility of establishing an international judicial organ for the trial of persons charged with genocide or other crimes over which jurisdiction will be conferred upon that organ by international conventions.

In carrying out this task, the ILC was to 'pay attention to the possibility of establishing a Criminal Chamber of the International Court of Justice'. 112

On 3 March 1950, it was concluded in a report by ILC Special Rapporteur Ricardo J. Alfaro that it was both 'desirable and feasible to institute an international criminal jurisdiction for the prevention and punishment of international

107 van Hoof, op. cit., 106.

108 See, e.g., E. Chadwick, 'A "reality-check" for international laws of war?' (2003) 39 Crime, Law \& Social Change 233, 245-248.

109 See, e.g., Legality of the Threat or Use of Nuclear Weapons, ICJ Rep. 1996, at 226.

110 See, e.g., Editorial Comments, Meron, 'War Crimes in Yugoslavia and the Development of lnternational Law' (1994) 88 AJIL 78, at 85 n. 37.

i1. Historical Survey, loc. cit., Prefatory Note.

112 Ibid. The ILC, a body established in accordance with UNGA Resolution 174(II) of 21 November 1947, was charged, inter alia, with the task of drafting a code of offences against peace and security in Resolution 177 (II) of 21 November 1947. Ibid., 31. 
crimes'. ${ }^{113}$ In contrast, ILC Special Rapporteur Emil Sandstrom, in a second report of the same date, came to the opposite conclusion, stating '[i]n my opinion the cons outweigh by far the pros. ${ }^{114}$ In large part, his adverse opinion was premised on the perceived flaws of Nuremberg:

With regard to the criticisms of the Nuremberg Trial, it can further be said that because of the haphazard way in which a permanent jurisdiction would be working, ..., and because of the impossibility of foreseeing the political events, there will be no guarantee against the same criticisms being raised against such a permanent jurisdiction. ${ }^{115}$

The immediate post-war environment in this regard was thus one of uncertainty for many reasons, not the least of which centred on whether draft work for an international criminal court should precede, follow, or accompany the development of a penal code. Work continued on both projects. What was to become the Rome Statute of 1998, and the now quite separate Draft Code of Crimes against the Peace and Security of Mankind, 116 initially were twinned, and drafts produced in 1951 and 1953. However, the UN General Assembly tabled the Court project in 1954, until the 'Code' project could be finalised. Both the Draft Statute, and the 1954 'Draft Code', 117 were then stalled until 'aggression' could be defined by the General Assembly. ${ }^{118}$ This occurred with Resolution 3314(XXIX) of 14 December 1974, but as that resolution was by consensus vote, 'aggression' remained a political concept, not a justiciable crime. ${ }^{119}$

In 1990, the ILC was invited by the General Assembly, in Resolution 45/41 of 28 November, to consider further the issues raised previously concerning the question of an international criminal jurisdiction, including the possibility of establishing an international criminal court or other international criminal trial mechanism. ${ }^{120}$ With the end of the Cold War, various initiatives took on an added urgency in relation to the prosecution of war criminals, not the least of which have resulted in the International Criminal Tribunals for the Former Yugoslavia, in 1993, ${ }^{121}$

113 'Question of International Criminal Jurisdiction', ILC doc. A/CN.4/15 (1950), reprinted (1950) 2 YBILC 20 (UN doc. A/CN.4/SER.A/1950/Add. 1, 6 June 1957), 17 para, 136.

114 'Question of International Criminal Jurisdiction', document A/CN.4/20, loc. cit., 23 para. 39.

115 Ibid., 23 paragraph 38a.

116 The text adopted by the ILC in 1996, and submitted to the UNGA, is reprinted (1996) 2(2) $Y B I L C$, at <http:/www.un.org/law/ilc/texts/dcode.htm>. See also UNGA Resolution $51 / 160(1997)$.

117 (1954) 2 YBILC.

118 See UNGA Resolution 897(IX) of 4 December 1954. Work on the Draft Code was remandated, in UNGA Resolution 36/106 of 10 December 1981, and recommenced properly in 1989 , pursuant to UNGA Resolution $44 / 39$, para. 1.

119 Bassiouni, op. cit., 8.

120 This invitation was renewed in UNGA Resolution $46 / 54$ of 9 December 1991.

121 Created pursuant to SC Res. 827, of 25 May 1993. See the 'Secretary-General's Report on Aspects of Establishing an International Tribunal', reprinted (1993) 32 ILM 1159. 
Rwanda, and more recently, Sierra Leone. However, it was specifically acknowledged, in the case of the ICTY, that:

[T]he Security Council's decision in Resolution 808 (1993) to establish an international tribunal is circumscribed in scope and purpose.... The decision does not relate to the establishment of an international criminal jurisdiction in general nor to the creation of an international criminal court of a permanent nature, issues which are and remain under active consideration by the I.L.C. and the General Assembly. ${ }^{122}$

The 'chicken or egg' positioning of the court and code projects during much of the post-1945 era, and the uncertainty thereby occasioned, was ultimately resolved by separating them. ${ }^{123}$ ILC work on a Draft Statute of an International Criminal Court was submitted in 1994 to the General Assembly, with the recommendation that the latter convene an international conference to conclude a convention for the establishment of the court. ${ }^{124}$

As regards harmonisation, the ILC comments, in relation to parallel work on the General Provisions of the Draft Code dealing, inter alia, with scope and application, that, although the progressive development of international criminal law and of the direct applicability of international law with respect to individual responsibility and punishment for crimes under international law largely began with the Nuremberg Tribunal, ${ }^{125}$ any pre-existing agreement is found only in relation to the principle that crime must be punished: ' $[\mathrm{t}] \mathrm{his}$ is in accord with the precedent of punishment for a crime under customary international law or general principles of law as recognised in the Nuremberg Judgement . . ${ }^{126}$ In other words, it is only in relation to the principle that crime must be punished that any general agreement to co-ordinate international crime control is found which pre-dates Nuremberg, a conclusion fully reflected in the approach taken in the ICC 37.

As for the jurisdiction of the $1 \mathrm{CC}$, a preliminary list of crimes included the Nuremberg offences - crimes against the peace (aggression), war crimes, and crimes against bumanity. The 1948 Genocide Convention was considered, as were international treaty crimes concerning terrorism. ${ }^{127}$ In relation to the latter, the ILC, in 1993 commentary, could distinguish between international terrorist treaties. Those in which crime is defined, such as the 1979 International Convention against the Taking of Hostages, permitted an international criminal court to apply basic treaty

122 'Secretary-General's Report', ibid., 1166, para. 12. See C. Tournaye, 'Genocidal Intent Before the ICTY' (2003) 52 ICLQ 447.

123 See, e.g., Current Developments, Rosenstock, 'The $45^{\text {th }}$ Session of the I.L.C.' (1994) 88 AJIL 134.

124 ILC Report, 1996, chp. II, loc. cit, Introduction, para. 38.

125 Ibid., Part 1. See, e.g., Commentary to Article 8 (Establishment of jurisdiction'), paras 3, 4,8 , and 12 .

126 (Emphasis added.) Ibid., Commentary to Article 3, para. 7.

127 See, e.g. 'Question of International Criminal Jurisdiction', document A/CN.4/15, cited note 113 above, 13, para. 100 . 
law, created a system of universal jurisdiction, and anticipated an international criminal tribunal, ${ }^{128}$ while mere 'behavioural' crimes did not. By 1994, the ILC included 'treaty crimes' where the prohibited acts, when systematic and sustained, constituted crimes of serious international concern, both within criminal categones of general international law, and more special international law, such as the Genocide Convention. ${ }^{129}$

By 1996, however, recommendations to include special crimes of international terrorism were dropped entirely, due largely to doctrinal disagreement in relation to the difficulty of distinguishing terrorism, per se, from the tactics of some wars of self-determination. ${ }^{130}$ Even though any distinction made in liberation theory between 'justifiable' and unjustifiable uses of violence mirrors that found in the laws of war between licit and illicit uses of armed force, it must remain a matter of speculation whether specific terrorist offences, for example, those relating to civil aviation, will be added to the article 5 crimes through the amendment processes contemplated in ICC, articles 121 and 123, or whether the ICC's jurisdiction can be stretched to cover crimes of a terrorist nature. In any event, state diversity in the prosecution of individuals for crime persists, despite the over-arching, pre-Nuremberg principle that 'crime must be punished', as is now discussed.

\section{DIFFICULTIES RAISED BY THE 'ROME' ICC}

\subsection{US Opposition}

The ICC utilises both a vertical and a borizontal approach to the exercise of international jurisdiction essentially through a choice in case referral under article 13. Specifically, article 13(b) referrals by the UN Security Council can transcend state territoriality, and are thus horizontal. Article 13(c) Prosecutorial initiative is yet another horizontal extension. In contrast, as the ICC is based on 'complementarity' in the context of state referrals under article 13(a), a universal scope to article 5 crimes is established, rather than universal jurisdiction. This leaves intact the more traditional, vertical approach to international law, and reflects a continuing political unwillingness to conform individual socio-legal systems for such purposes, which in turn arguably places the desirability of a universalist approach to underlying concept in some doubt.

A strong vertical approach to state sovereignty, in terms of enforcement capability, is also implicit in the UN Charter. Without the particular distribution of power and authority found in the UN Charter, it is even to be speculated the US

128 ILC Report, 1993, UNGAOR 48 ${ }^{\text {th }}$ Sess. Supp. No. 10 (A/48/10), Commentary, article 22, at $272-273$.

129 ILC Report, 1994, GAOR 48 ${ }^{\text {th }}$ Sess. Supp. No. 10 (A/49/10), at 78-79.

130 See, e.g., V. Morris and M.-C. Bourloyannis-Vrailas, 'The Work of the Sixth Committee at the Fiftieth Session of the U.N.G.A.' (1996) 90 AJIL 491, 493. This was despite the adoption at the previous session of the Declaration on Measures to Eliminate International Terrorism. UNGA Resolution $49 / 60$ (1995). 
would not have joined, or been a founder of, the organization. As was noted in 1947, 'the makers of the United Nations-chief among which was the United States created a political rather than a legal system'. ${ }^{131}$ Specifically, at that time, it was not thought the Security Council would necessarily consult law in its handling of disputes, ${ }^{132}$ or would view international law as a yardstick regarding domestic questions for charter purposes. ${ }^{133}$ Accordingly, the US has expressed 'fundamental concern' with the horizontal reach of law designed into the $\mathrm{ICC}^{134}$ as a major shift in power politics. ${ }^{135}$

In particular, one difficulty for the US is that if it wishes to stop an investigation and/or prosecution, it will be unable to do so through Security Council resolution unless it has the agreement of the other permanent members and four nonpermanent members. A decision by the Security Council to tefer a case must be taken under chapter VII of the UN Charter, which, in accordance with charter article $27(3)$, requires 'an affirmative vote of nine members including the concurring votes of the permanent members'. ${ }^{136}$ This gives each permanent member the veto power, even in situations involving itself. ${ }^{137}$ Therefore, a borizontal exercise of universal jurisdiction - in the sense of transcending the territoriality of a state party - by the Security Council over article 5 crimes can be blocked by one permanent member. Conversely, should the court be seized either by a state or through prosecutorial initiative, the proceedings can be blocked, as the Security Council, acting again under chapter VII, may defer an investigation or prosecution for twelve months, renewable. In the latter situation, however, and crucially, deferral must also comply with charter article $27(3)$.

A further consequence of the court acting in article 13(a) cases involving the territory or citizens of ratifying states ${ }^{138}$ is an extension of international control over what are at present crimes defined within the political frameworks of domestic

131 Editorial Comment, Eagleton, 'The Task of the International Lawyer' (1947) 41 AJL 435, 436. See also M. Byers, 'The World according to Cheney, Rice and Rumsfeld', London Review of Books, 21 February $2002,14$.

132 See Editorial Comment, Eagleton, loc. cit. 436.

133 The Security Council is merely under a general dury to uphold a UN Charter through which the maintenance of international law is sought. But see League Covenant, article 15(8), discussed by $L$. Gross, 'The Charter of the United Nations and the Lodge Reservations' (1947) 41 AJIL 531, 538-544.

134 See the Lawyers Committee for Human Rights, cited note 50 above.

135 See, e.g., J. Sutherland, 'Who are America's real enemies?', The Guardian G2,8 July 2002, 6 ('we're not Panama' riposte to the American Service-members' Protection Act, which permits the use of force against the Netherlands to free a national held by the ICC). But see Editorial Comment, Brown, 'The Interpretation of the General Pact for the Renunciation of War' (1929) 23 AJIL 374, 375 (Senatot Borah maintains that 'every nation reserved the right to employ force to protect its nationals when their lives might be endangered in foreign lands').

136 Abstention by a permanent member does not constitute a veto. Harris, op. cit., 685, citing the Legal Consequences Case, ICJ Rep. 1971, 16, 22.

137 As occurred in 1982, when the UK vetoed a draft resolution calling for a cease-fire during the Falklands War. Harris, op. cit., 666.

138 Article 12(2). 
criminal law. Specifically, the different interpretations afforded to, and enforcement of, domestic penal laws which have arisen from varied socio-political systems can now be superseded, even though it is certainly the case that the requirements for admissibility to investigate and/or prosecute before the court are stringent. In view of the harmonised approach to the elements of the article 5 crimes to be employed by the court, there will, in effect, be a superior global enforcement body for newly nominated international crimes: crimes against bumanity unrelated to war, ${ }^{139}$ and aggression; crimes of war and genocide are already prohibited by treaty.

The difficulty in such a shift is this. As implementation of the UN Charter is incomplete, ${ }^{140}$ international law is enforced vertically. In that the ICC is designed to act as a superior enforcement body, the resulting transfer of power from states to the court could result theoretically in the trial of citizens of non-ratifying states. For those states which have accepted the jurisdiction of the court, this was foreseeable; moreover, individual states already possess the sovereign right to proscribe certain conduct occurring in national territory. Nevertheless, the competence of what is now an additional forum, and the use of what might be termed 'new' law, constitutes the extension of a law-and-order approach to what was previously achievable, if at all, via political filters and considerations of intemational comity. The ICC could thus greatly disturb the existing distribution of power and authority originally designed into the United Nations Charter.

Furthermore, by providing a degree of political distance from individual state responsibility for successful convictions pursuant to $\mathrm{ICC}$, article 5 , ratifying states have arguably gained a mechanism enabling them, albeit indirectly, to prosecute each other, or at the least, each other's policy decisions. While acceptance of the court's jurisdiction is tantamount to an acceptance of external interference in matters that used to be domestic, a legal approach to the perpetrators of article 5 crimes side-steps allegations of international delinquency, for example, of state sponsorship. ${ }^{141}$ This minimises considerations other than a perpetrator's actus reus, although it will still be necessary to consider intent to gauge the significance and extent of any putative authonity over the perpetration of a relevant crime. As for the traditional need to evaluate the probity of sister-state legal systems prior to a decision to extradite or prosecute an offender, the option of a referral under article 13(a) necessitates less concern both for over-arching geo-political considerations, and cultural and ethical relativism.

139 The ILC notes, cited in note 61, above, at para. 6, Commentary to Article 18, that the autonomy of crimes against humanity is recognised partially in the Genocide Convention, and territorially in Allied Control Council Law No. 10 of 20 December 1945 and the Statutes of the ICT for the former Yugoslavia and Rwanda.

140 Specifically, until UN Charter, article 43, military agreements exist, action taken under article 42 must depend on Security Council consensus to provide the necessary resources. For a discussion of Charter articles 41 and 42 , see $R$. McLaughlin, "United Nations Mandated Naval Interdiction Operations in the Territorial Sea?' (2002) 51 ICLQ 249.

141 ICC, article 25(4), states: '[n] provision in this Statute relating to individual criminal responsibility shall affect the responsibility of states under international law'. But see ICC, article 98. 
Moreover, the maintenance of international peace traditionally has frequently depended upon the success of a balance maintained with the principle of non-interference in sister-state domestic affairs. This equilibrium is now at risk due to the separate, and superior, enforcement capability contemplated in the ICC. ${ }^{142}$ For example, heretofore, a desire to prevent damage to international relations has been paramount in much state decision-making regarding the prosecution of persons deemed international criminals. ${ }^{143}$ One consequence of this consideration, and of the enforcement of international law by states generally, is that protective international legal mechanisms traditionally bave constituted mere auxiliary means to formalise the duties of states in relation to individuals. The consistent application of this structure in the post-1945 era, as evidenced positively through state agreement and practice, is now in danger of being overtumed by the adoption of a multilateral instrument which relies on a putatively superior Grundnorm. ${ }^{144}$

Until adherence to the ICC becomes universal, the seeming simplicity of approach to harmonised law-making found in it cannot reflect the expression of existing international criminal law. While great strides have been made in the progressive development of international conventional law since the Nuremberg and Tokyo War Crimes Tribunals, there remains a lack of much-needed critical foundation to this new exercise in international scrutiny and accountability. In instituting a court that will utilise a harmonised approach to the article 5 crimes, and, a 'legal' crime of aggression in particular, a leaching away - via multilateral treaty has begun of the political discretion left to be exercised either by individual states acting in their sovereign capacity, or the Security Council. This, in the absence of express agreement through treaty ratification, could result in the imposition on unwilling states of legal standards which have not yet acquired the status of customary international law, itself a combination of opinio juris and state practice, as is now discussed.

\subsection{UN Charter Article 42-1/2?}

Assuming, for purposes of argument, that the ICC, article 5, crimes against humanity, and of war, genocide, and aggression form part of the law of the land, and hence, that states remain under a continuing obligation either to incorporate or transpose such prohibitions into their domestic policies and legal systems, there should be little hesitation, or difficulty, in pooling together sovereign control mechanisms into a superior enforcement capability. However, the potential for conflict between international and state-centric approaches to responsibility for international crime goes to the structural heart of the United Nations.

142 Note the negative Preambular duty in the ICC: 'Emphasising ... that nothing in this Statute shall be taken as authorising any State Party to intervene in an armed conflict or in the internal affairs of any State'. Contrast F.R. Lee, 'Constitutionally, a Risky Business', NYTimes.com, 31 May 2003.

143 See, e.g., Chadwick, Self-Determination (Etc.), loc. cit., Chapter 8.

144 See, e.g., Safferling, op. cit., 48-53. 
First, in relation to the maintenance of international peace and security under the UN Charter, the Security Council holds the primary responsibility for its restoration pursuant to charter article 24(1). Charter article 39 states ' $[t]$ he Security Council shall determine the existence of any threat to the peace, breach of the peace, or act of aggression. . .' in relation to the maintenance of international peace and security. Such threats, breaches or acts may occur in times of war, as well as those of notional peace. As remarked earlier, determinations under article 39 are inherently political in nature.

The original intent bebind charter article 42 was to make directly enforceable any armed measures agreed by the Security Council pursuant to a determination under article 39 to restore international peace and security. ${ }^{145}$ Articles $43-50$ were designed to make concrete the Security Council's ability to do this. However, direct action by the Security Council under article 42 has never been possible, as the necessary military agreements envisaged in article 43 , for the maintenance of stable armed forces, have never been forged. The main difficulty has hinged on disagreement among the five permanent members of the Security Council as to the specific contributions of each. ${ }^{146}$ While this lack of agreement may in large part be attributable to the Cold War, it can equally be understood on the basis that a fixed hierarchy of military responsibility would have emerged among the five permanent members which otherwise were to operate on lines of equality.

Thus, regardless of opposing political ideologies, charter article 43 was infused with an inherently political aspect from the start, rather than the purely technical character which should have prevailed. As such, the Security Council is unable to order states to participate in armed enforcement measures authorised under article 42 to restore international peace and security. In turn, states not wishing to become militarily involved in UN activities taken under article 42 need not. In this connection, Gioia notes:

Under Charter Article 106, which was to apply 'pending the coming into force of such special agreements referred to in Article 43', the parties to the Four-Nation declaration, signed at Moscow on 30 October 1943, plus France, were empowered to 'consult with one another and as occasion requires with other Members of the United Nations with a view to such joint action on

145 UN Charter, article 42, states:

Should the Security Council consider that measures provided for in Article 41 would be inadequate or have proved to be inadequate, it may take such action by air, sea, or land forces as may be necessary to maintain ot restore international peace or security. Such action may include demonstrations, blockade, and other operations by air, sea, or land forces of Members of the U.N.

Article 43(1) states:

All Members of the U.N., in order to contribute to the maintenance of international peace and security, undertake to make available to the Security Council, on its call and in accordance with a special agreement or agreements, armed forces, assistance, and facilities, including rights of passage, necessary for the purpose of maintaining international peace and security.

146 See, e.g., Harris, op. cit., 680-681. 
behalf of the Organisation as may be necessary for the purpose of maintaining international peace and security'. Be the present status of this provision as it may, there would be no duty on the part of U.N. Members to join in military action undertaken by the five Powers 'on behalf of the Organisation'. ${ }^{147}$

Therefore, in relation to the armed preservation or restoration of international peace and security, there is no right to call on states to act, nor is there any positive state duty so to act. ${ }^{148}$ The Security Council is unable by right to require states to utilise force to prevent the occurrence or continuation of situations in which the nominated article 5 crimes against humanity, and of war, genocide and aggression occur. There is instead only a power to request assistance, which states remain at liberty to reject. In turn, the existence of a power, rather than a right/duty correlation, fully reflects the lack of means available at present to enforce 'legal' determinations for these purposes. As such, Security Council determinations under article 39 remain inherently political. In this respect, international law remains a primitive legal system, and the sovereign independence of states, a basic feature of international society.

Nor has any determination, judicial or otherwise, been made that customary international law has emerged such as would imply a right/duty correlation in relation to UN direct armed intervention to prevent the occurrence of article 5 crimes. ${ }^{149}$ As noted by van Hoof, ${ }^{150}$ one of the most fundamental aspects of the international law-making process is that 'the consent of states has to be regarded as the constitutive element of rules of international law'. In relation to the development of law through multilateral treaty, only accepting states are bound. ${ }^{151}$ Custom, on the other hand, requires sufficient evidence that states accept they are bound by a principle. While 'consent' can be evidenced in various ways, the fact remains that an intention to be bound by legal rules must be manifest. In other words, the consent of states cannot be assumed, but must be made obvious through state practice, in the sense of demonstrating a legal obligation so to act. To argue that

147 A. Gioia, 'Neutrality and Non-Belligerency', in H.H.G. Post, (ed.), Intemational Economic Law and Amed Confict (1994), 51, 73 n.77.

148 Conversely, decisions on measures falling short of the use of armed force, taken under article 41 , are binding on states members.

149 As distinct from the customary international law principles of the non-use of force expressed in UN Charter article 2(4), and of non-intervention. See Case Concerning Military and Paramilitary Activities in and against Nicaragua, ICJ Rep. 1986, 14, paras. 188-249. Moreover, international violence is not merely a question of third state interference or sponsorship.

150 van Hoof, op. cit, 76.

15. The 1969 Vienna Convention on the Law of Treaties, reprinted (1969) 8 ILM 679, and 63 $A J I L$ 875, states, at article 34 : '[a] treaty does not create either obligations or rights for a third State without its consent'. US adherence to the obligations of the Vienna Convention on the Law of Treaties has now been endangered, as it has 'un-signed' the Rome Statute. N.A. Lewis, 'U.S. Rejects All Support for New Court on Atrocities', NYTimes.com, 7 May 2002 (states must refrain from undermining treaties they have signed). 
either consent or practice alone is sufficient to create customary international law is to ignore the importance of one of its requisite components. ${ }^{152}$

Therefore, if no right/duty correlation exists in international law directly to stop or prevent a situation in which one or more of the ICC, article 5, offences is occurring, then the seizing of an international forum with enforcement capability for the prosecution of individuals alleged to have perpetrated such offences in a systematic manner is missing a critical foundation in customary international law. The concurrence of state consent and practice in creating a hierarchy of norms in international law, or a recognition of norms that are of fundamental importance for the international community, must be present before a responsibility to maintain those norms systematically can be viewed as grounded in custom. Thus, while the Nuremberg and Tokyo Tribunals gave recognition to an international law of individual responsibility in relation to the perpetration of violent acts, also highlighted are the serious difficulties created by the 'web of connection' existing between individual responsibility and that of groups, including nations and states, regarding the use of force.

Foregrounded is the enduring distinction found in criminal law theory in relation to the element of intent. 'Legal' determinations of guilt made pursuant to ICC, article 5, are in respect of individuals over whom custody can be obtained; the ICC constitutes a superior enforcement mechanism to prosecute only those individuals who can be captured. ${ }^{153}$ Given the obvious dangers of opportunistic admissibility, and of ratification only by what are at the time of writing fewer than half of the world's states, it cannot be said there is sufficient evidence of consensus to substantiate the 'creation' of a truly autonomous, consistent, body of international criminal law. On the contrary, one is reminded less of mighty winds than of smoke-filled rooms. The politicisation of the court must be anticipated, as must be the law to be applied by it.

\subsection{Nullum crimen sine lege?}

While there are no direct enforcement duties in international relations, it cannot be said that there is no existing law in relation to the ICC, article 5, offences. As discussed earlier, two of the article 5 offences - war crimes and genocide - already find expression in international jurisdiction through treaty. Individual crimes against humanity are locatable within different human rights documents, and aggression remains undefined in law. The difficulty, as noted by Bassiouni, ${ }^{154}$ is as follows:

152 For discussion on this point, see van Hoof, op. cit, 86-90.

153 Which potentially further undermines the operation of bi- and multilateral treaties regarding extradition, and mutual legal assistance in criminal matters. See, e.g., Current Developments, Morris and Bourloyannis-Vrailas, ${ }^{4}$ Report of the I.L.C. on the Work of its 45th Session' (1994) 88 AJIL 349, 351.

154 Bassiouni, loc. cit., 152. 
Universal jurisdiction resembles a checkerboard. Some conventions recognise it and some national practices of states demonstrate its existence, but it is uneven and inconsistent. Most of all, the practice of states does not evidence its consistent or widespread application.

One reason for such inconsistency in practice is that the four article 5 offences concern systematic or large-scale behaviour perpetrated during times of war and peace, as well as by state and non-state actors. A strict approach to crime is thus adopted which risks ignoring political variations in-built over time through individual state implementation; for example, state approaches to the three offences already attracting legal recognition vary in relation to whether the perpetrators are made amenable to state systems of public order, or engage any immunity rules. To equate what is essentially an unquestioned moral authority with a legal one is as misguided as any presumption of equivalence between principle and implementation. Accordingly, a distinction between universal condemnation, at one end of the political spectrum, and universal jurisdiction, at the other, is upheld through a corresponding distinction between prescriptive, and enforcement, jurisdiction.

States ratifying the ICC 37, in conjunction with the Terrorism Convention, would have utilised both a common legal approach to terrorist offences, and their own substantive law. The present ICC takes the opposite approach, in that there would appear to be little in the way of a common state approach to the article 5 offences, yet the substantive law to be applied before the court is potentially made applicable to anyone. The differentiation in the assertion of jurisdiction, on the one hand, pursuant to article 13(a), and on the other, article $13(b)$, confirms the distinctions inherent in the distribution of power contained in the UN Charter. However, the basis for jurisdiction found in article 13(c) represents a new departure from the pre-existing balance of power. Given that the Rome Statute is reliant on an 'autonomous' international legal community, so-called, yet is notionally binding only on ratifying states, any assumed consensus in relation to 'global' accountability for crime must be viewed as wildly exaggerated, not least because the US opposes, in particular, the possibjility of state-actor prosecutions. ${ }^{155}$ As noted by Bassiouni: ${ }^{156}$

[I]t is easier for states to recognise and apply the theory of universality and other enforcement modalities to [individuals and small groups], than to do so with respect to those who carry out state policy. This explains why, notwithstanding the extensive harm caused by genocide and crimes against humanity, states have been reluctant to have the same enforcement obligations apply as they have provided, for example, with respect to 'terrorism'and international drug trafficking. It is this writer's contention [that] international criminal law conventions whose subjects are those

155 See A. Nollkaemper, 'Concurrence between Individual Responsibility and State Responsibility in International Law' (2003) 52 ICLQ 615.

156 Bassiouni, loc. cit. 134. 
persons engaging in state action or carrying out state policy contain less effective enforcement mechanisms than other similar international conventions.

While the ICC 37 would also have linked territory and sovereignty to terrorist offenders, with the associated potential to try official actors of non-ratifying states, it must remain a matter of speculation whether this would ever have occurred. ${ }^{157}$

Gaps exist in the state prohibition of crimes afforded universal jurisdiction to the extent that sovereign discretion to implement international rules in accordance with perceived needs exists. As a result, many states continue to require a linkage between their exercise of criminal jurisdiction and nationality or territory. Therefore, not only does the fact of prosecution differ state-to-state, ${ }^{158}$ but such trials as are held are subject to different laws, procedures, and interpretations; there is no customary international law or procedural treaty to conform internationally the instigation or outcome of such actions. In turn, to allege the existence of a notional unitary norm in existing patterns of co-operation invites instead a search for deviance from it, such as to reveal dissonance in relation to issues of content, and hence, of concept, concerning international crimes, not the least of which would, no doubt, involve the degree to which each of them is even amenable to legal definition.

\section{CONCLUSION}

The ICCs of 1937 and 1998 differ far more than they resemble. On the one hand, the 1937 codifications required states to prosecute and punish particular terrorist acts of an international character. Otherwise, ratifying states would have retained their powers of sovereign control. The present ICC, in contrast, facilitates a transfer of substantive competence from sovereign states to an international forum, to prosecute 'serious' article 5 offences. Conventions for the organization of two international criminal courts have thus been opened for signature and ratification in the 20 th century, and it is certainly to be hoped that the latter convention enjoys a more mature response from the international community than did the former.

Perhaps the time has arrived for the world community to proscribe, strictly, the perpetration of certain acts. In particular, a legal definition for the crime of aggression would 'make intemational self-defence legally meaningful'. ${ }^{159}$ The non-entry

157 Particularly as the renunciation of war as an instrument of national policy contained in the Kellogg-Briand Pact of 1928 recognised the legality of war, and was sanctionless. See E. Chadwick, 'To the Victors the (Legal) Spoils?', in Traditional Neutrality Revisited, op. cit., 129, 132-142.

158 See, e.g., the examples given by Bassiouni, loc. cit, 147-148, n. 227.

159 Editorial Comment, Kunz, "Individual and Collective Self-Defence in Article 51 of the U.N. Charter' (1947) 41 AJIL 872, 876. The political origins of determinations of aggression also open the door to an increased reliance on so-called humanitarian intervention. 
into force of the 1937 treaties was certainly affected by the rapid approach of a world war fought for divergent ideologies, ${ }^{160}$ and in a manner which depended as much on those ideologies as on new technology. It therefore needs remembering that the Terrorism Convention and ICC 37 were worthy, if failed, attempts to deal collectively with a major cause of international friction: acts of politically-motivated terrorism of an international character, which, unfortunately, can be supported and financed by state and non-state actors alike.

No attempt was made in the ICC 37 to develop a substantive international criminal law. Complicating this picture, the prosecution of politically-motivated actors can prove particularly objectionable to a government sympathetic with a terrorist's political motivation, or which maintains traditions of asylum. However politically relevant such objections may remain today concerning 'the most serious crimes' of genocide, of war, against humanity, and of aggression, it is nonetheless the case that the failure to achieve co-operation in 1937 regarding the suppression of terrorism is but one indication of the degree to which many state and non-state actors prefer not to confront a genre of criminal acts they are themselves prepared to utilise.

Notwithstanding the above, it remains the case that customary international law requires sufficient evidence of state consent and practice for its positive identifcation. Otherwise, developments in international law are subject to treaty, such that only consenting states are bound. To assert that a legal standard is binding on states without evidence of custom or treaty participation is tantamount to constructing a hierarchy within what otherwise is a system built on sovereign equality. While it is true that the prohibition on the use of force in international relations 'should' restrain any state's enforcement, or breach, of post-1945 customary international law, it remains the case that disagreement as to content and concept remain. Absent the use of superior force, or a coalition of the willing, there is no enforcement mechanism in existence with which directly to prevent atrocities perpetrated systematically by individuals. Whether or not a superior legal enforcement mechanism such as the ICC can possibly succeed within what is inherently a political environment remains to be seen.

160 See, e.g., speech by Mussolini on 7 October 1934, in which he attributes only two alternatives to the 'irrevocable decline of the capitalist civilisation: the Communist and the corporative'. Keesings Archives, 1393. 